\title{
Gagasan Emansipasi Wanita melalui Konsep Tokoh Kartini
}

\author{
Tri Riya Anggraini
}

\author{
STKIP PGRI Bandar Lampung, Lampung, Indonesia \\ tri260211@gmail.com
}

\begin{abstract}
The purpose of this study is to imply two of Pradotokusumo's theories. First, modification, namely changes related to the linguistic and literary level. Second, ekserp, namely the absorption of an element or episode of the hypogram. The hypogram in this text is the idea of the emancipation of women contained in "Surat-Surat Kartini: Renungan Tentang dan Untuk Bangsanya". The literary works discussed in this regard are "Siti Nurbaya" by Marah Rusli, and "Layar Terkembang” by Sutan Takdir Alisyahbana. This research is a qualitative through literature study. The research stages were carried out by collecting literature sources. The results showed that the hypogram or reference text was the background for the creation of other literary texts. Literary work always creates a different understanding for each reader which is the basis of the aesthetic theory of reception, specifically, (1) the principle of the horizon of hope (erwanstunshorizont) and (2) the open space (leerstelle).
\end{abstract}

Keywords: hypogram, reception aesthetics, Kartini character, woman emancipation

Abstrak : Tujuan penelitian ini adalah mengimplikasikan dua teori Pradotokusumo. Pertama, modifikasi, yaitu perubahan yang berhubungan dengan tataran linguistik dan tataran kesusasteraan. Kedua ekserp, yaitu penyerapan suatu unsur atau episode dari hipogram. Hipogram dalam teks ini adalah gagasan emansipasi wanita yang terdapat dalam Surat-Surat Kartini; Renungan tentang dan untuk Bangsanya. Karya sastra yang dibahas dalam hal ini adalah novel Siti Nurbaya karya Marah Rusli, dan novel Layar Terkembang karya Sutan Takdir Alisyahbana. Penelitian ini merupakan jenis kualitatif melalui studi pustaka. Tahapan penelitian dilaksanakan dengan menghimpun sumber kepustakaan. Hasil penelitian menunjukkan bahwa hipogram atau teks acuan merupakan teks yang menjadi latar penciptaan teks karya sastra lain. Karya sastra selalu menimbulkan pemahaman yang berbeda terhadap masing-masing pembaca yang merupakan dasar teori estetika resepsi, yaitu, (1) prinsip horizon harapan (erwanstuns horizont) dan (2) tempat terbuka (leerstelle).

Kata kunci: hipogram, estetika resepsi, tokoh Kartini, emansipasi wanita 


\section{Pendahuluan}

Studi tentang wanita (woman study) dalam sejarah Indonesia merupakan studi yang jauh tertinggal bila dibandingkan dengan bidang ilmu sosial yang lain. Penelitian tentang peranan wanita dalam sektor sosial, ketenagakerjaan, dan keluarga berencana merupakan tema-tema yang telah lama menjadi bahan penelitian dalam sosiologi. Namun, woman study tetap belum memperoleh kedudukan sendiri dalam ilmu-ilmu sosial di negeri ini.

Dalam hal ini Subandiyah (1996: 3) mengatakan bahwa sastra adalah sarana efektif untuk menerjemahkan dunia batin perempuan. Melalui sastra, dunia batin perempuan yang meliputi potret diri, pemikiran-pemikiran, sikap-sikap, dan emosi perempuan dapat dilihat dengan jelas terutama dalam novel. Pembaca dapat memotret perempuan baik sebagai makhluk individu maupun makhluk sosial.

Akhir-akhir ini, studi tentang wanita telah menarik perhatian dari pelbagai ahli. Barangkali menjadi tren munculnya tokohtokoh wanita dalam tampuk kekuasaan politik di Asia akhir-akhir ini menjadikannya sebagai momentum bagi tumbuhnya minat terhadap kajian tentang wanita. Megawati Sukarno Putri (Indonesia), Gloria Macapagal Arroyo (Philipina), Shek Hazina (Bangladesh), Benazir Bhuto (Pakistan), Indira Gandhi, Sonia Gandhi (India), dan lain-lain memberikan penegasan bahwa wanita dapat tampil sebagai aktor yang memiliki kekuatan dan kemampuan untuk memimpin suatu masyarakat dan bahkan menjadi top leader bagi bangsanya.

Sebenarnya apabila membuka lembaran sejarah nasional Indonesia, maka
Volume 3, Nomor 1, Januari 2021 ISSN 2655-3031 (P), 2655-7851 (O) DOI: http://dx.doi.org/10.29300/disastra.v3i1.3481

akan dapat dijumpai tampilnya tokoh-tokoh wanita yang berperan dalam upaya meningkatkan peranan dan eksistensi bangsa ini melalui berbagai bidang. Namun, keterbatasan sumber dan sekali lagi karena kajian tentang wanita belum mendapatkan tempat yang layak sehingga belum banyak tokoh-tokoh wanita dalam sejarah Indonesia yang dikaji secara intensif dan mendalam. Kartini merupakan satu diantara sekian banyak tokoh wanita Indonesia yang telah mendapat perhatian. Hal ini karena semata-mata beliau meninggalkan pemikiran-pemikiran yang dapat dirunut dari surat-suratnya yang telah dibukukan. Perjuangan dan pemikirannya tentang emansipasi wanita telah dirasakan gaungnya sejak lama. Hal itu dapat diketahui dari karya sastra yang telah dipublikasikan.

Karya sastra terlahir dari pikiran pengarang. Dalam proses menghasilkan sebuah karya sastra, pengarang tidak hanya bertindak sebagai produktor namun pengarang juga lebih dahulu sebagai reseptor. Pengarang tidak secara langsung mengalihkan karya sastra lama ke dalam karya sastra baru, melainkan melalui proses kreativitas pengarang dengan kemampuan imajinasinya. Dengan kata lain telah terjadi hubungan antarteks.

Dalam memahami karya sastra secara utuh perlu dicari hubungannya dengan teks lain. Teks yang menjadi latar penciptaan teks karya sastra lain oleh Riffaterre (dalam Pradopo, 1995) disebut sebagai hipogram atau teks acuan. Teks yang menjadi hipogram ini akan diserap dan ditransformasikan sebagai karya sastra baru. Sehubungan dengan latar penciptaan teks sastra, karya sastra selalu 
menimbulkan pemahaman yang berbeda terhadap masing-masing pembaca. Karya sastra selalu memberi wajah berbeda kepada pembaca yang satu dengan pembaca yang lain, dari satu generasi kepada generasi lain (Jauss dalam Pradopo, 1995).

Perbedaan pembacaan, pemaknaan, dan penerimaan karya sastra dari pembaca yang satu kepada pembaca yang lain, dari satu periode ke periode yang lain itu disebabkan oleh dua hal yang merupakan dasar teori estetika resepsi, yaitu (1) prinsip horizon harapan (erwanstunshorizont) dan (2) tempat terbuka (leerstelle). Tulisan ini menerapkan kedua konsep yang dikemukakan Jauss, yaitu pemahaman karya sastra oleh pembaca masa lampau atau resepsi historis dan pemahaman karya sastra lama oleh pembaca masa kini atau resepsi hermeneutik. Hipogram dalam teks ini adalah gagasan emansipasi wanita yang terdapat dalam Surat-Surat Kartini; Renungan tentang dan untuk Bangsanya. Karya sastra yang dibahas dalam hal ini adalah novel Siti Nurbaya karya Marah Rusli, dan novel Layar Terkembang karya Sutan Takdir Alisyahbana.

Tong (2006: 65) menjelaskan bahwa laki-laki, seperti juga perempuan, harus memperlakukan satu sama lain sebagai seorang yang setara sebagai manusia yang sama berharganya untuk dicintai. Pendapat di atas menjelaskan peran perempuan yang sama berharganya dengan laki-laki.

Terkait dengan hal tersebut, emansipasi adalah pandangan seseorang tentang persamaan hak di antara laki-laki dan perempuan. Emansipasi wanita di Indonesia dinamakan sebagai gerakan pembebasan kaum wanita dari
Volume 3, Nomor 1, Januari 2021

ISSN 2655-3031 (P), 2655-7851 (O)

DOI: http://dx.doi.org/10.29300/disastra.v3i1.3481

ketergantungan pada orang lain, terutama pada kaum laki-laki (Munandar, 1985: 17).

Emansipasi ialah istilah yang digunakan untuk menjelaskan sejumlah usaha untuk mendapatkan hak politik maupun persamaan derajat, sering bagi kelompok yang tak diberi hak secara spesifik, atau secara lebih umum dalam pembahasan masalah seperti itu. (Achmad Syafi'I Ma'ani, 2013).

Emansipasi merupakan salah satu gerakan feminisme dengan menggabungkan doktrin persamaan hak bagi perempuan yang menjadi gerakan yang terorganisasikan untuk mencapai hak asasi perempuan yang berangkat dari suatu kesadaran akan suatu penindasan dan pemerasan terhadap perempuan dalam masyarakat baik dibidang politik, ekonomi, pendidikan, dan sosial (Wahono, Haryati \& Sumartini, 2015: 5).

Penelitian yang ditulis oleh Widyani (2008) dengan judul "Relevansi Pemikiran Pendidikan R.A. Kartini dengan konsep Feminisme dalam Pendidikan Islam", berdasarkan analisisnya peneliti menyimpulkan bahwa pemikiran Kartini tentang pendidikan relevan dengan Pendidikan Islam. Berbeda dengan penelitian yang dilakukan peneliti. Peneliti mencoba mendeskripsikan bagaimana emansipasi wanita yang ditinjau modifikasi dan eksperp pada teori Pradotokusumo.

Emansipasi wanita pertama kali diangkat dalam karya sastra modern dalam bentuk novel, yaitu "Siti Nurbaya"(1922) karya Marah Rusli. Sesungguhnya gagasan emansipasi wanita ini berhubungan juga dengan masalah adat (kawin paksa, poligami). Gagasan emansipasi wanita kemudian diangkat secara khusus oleh 
Sutan Takdir Alisyabana "Layar Terkembang"(1936). Kedua novel ini dipandang memiliki kesamaan cerita dengan Surat-Surat Kartini, Renungan tentang dan untuk Bangsanya sehingga dapat dipastikan bahwa kedua karya ini merupakan karya turunan dari hipogramnya (Surat-Surat Kartini, Renungan tentang dan untuk Bangsanya). Oleh karena itu, pembicaraan mengenai konsep Kartini pada kedua teks tersebut diperlukan kajian intertekstual.

Riffaterre dalam Endraswara(2008) mengemukakan bahwa hipogram dapat berupa ekspansi, yaitu perluasan atau pengembangan hipogram; konversi, yaitu pemutarbalikan hipogram atau matriknya. Selain itu Pradotokusumo dalam Ratnawati (2001) juga menambahkan dua cara lain. Pertama, modifikasi, yaitu perubahan yang berhubungan dengan tataran linguistik dan tataran kesusasteraan. Dan kedua ekserp, yaitu penyerapan suatu unsur atau episode dari hipogram.

Tujuan penelitian ini adalah mengimplikasikan dua teori Pradotokusumo. Pertama, modifikasi, yaitu perubahan yang berhubungan dengan tataran linguistik dan tataran kesusasteraan. Kedua ekserp, yaitu penyerapan suatu unsur atau episode dari hipogram

\section{Metode Penelitian}

Metode penelitian yang digunakan dalam penelitian ini adalah metode deskriptif. Pendeskripsian data-data dari hasil penerapan modifikasi dan ekserp seperti yang dikemukakan Pradotokususmo. Sumber data berasal dari novel Siti Nurbaya dan Layar Terkembang. Selanjutnya, teknik pengumpulan data yang
Volume 3, Nomor 1, Januari 2021 ISSN 2655-3031 (P), 2655-7851 (O) DOI: http://dx.doi.org/10.29300/disastra.v3i1.3481

digunakan peneltian ini adalah analisis dokumen yang dimulai dari tahap pembacaan, pencatatan, dan analisis.

Berdasarkan Fairclough (1995:98) analisis data penelitian ini dilakukan dalam tiga level, yaitu mikro, meso, dan makro dengan mengacu pada CDA model Norman Fairclough. Pertama, analisis teks atau analisis mikro (proses produksi) berfokus pada pendeskripsian mengenai teks, yaitu dengan cara menganalisis teks yang berfokus pada isi teks, lokasi, sikap dan tindakan tokoh dan sebagainya, untuk memperoleh data yang dapat menggambarkan representasi teks. Kedua, analisis discourse practice atau analisis meso (proses interpretasi) berfokus pada dua aspek, yaitu produksi teks dan konsumsi teks. Ketiga, analisis sociocultural practice atau analisis makro (proses wacana), berfokus pada hubungan antara wacana dengan fenomena atau konteks sosial di mana teks dibuat.

\section{Hasil dan Pembahasan}

Pada bagian ini akan dibahas hasil penelitian, yaitu sebagai berikut.

\section{A. Novel Siti Nurbaya Karya Marah Rusli}

Gagasan ini secara khusus dibicarakan dalam siti nurbaya pada bab XII "Percakapan Nurbaya dengan Alimah" (hlm.203-222). Dalam percakapan Ahmad Maulana dengan Fatimah, istrinya, tentang Rapiah yang meninggal karena sakit diterjang Sutan Hamzah. Rapiah bertengkar dan berkelahi dengan Sutan hamzah karena marah dengan Sutan Hamzah yang kawin lagi. Sutan Hamzah mempunyai beberapa isteri. Dikemukakan di sini masalah poligami yang mencelakakan kaum 
perempuan dan anak-anaknya. Nurbaya mendengar percakapan itu sangat sedih dan menangis.

Ahmad maulana sendiri tidak setuju dengan poligami yang banyak menimbulkan bencana bagi kaum perempuan (hlm.205). Akan tetapi, sudah menjadi adat Minangkabau bahwa bagaimana hendak diubah, begitu kata isterinya. Adat dan budaya yang sudah mengental membuat wanita tak mampu untuk bertindak. Hal ini nampak pada ulasan tersebut.

Ahmad Maulana mengemukakan bahwa poligami itu tidak baik karena perkawinan itu dipandang sebagai perdagangan. Di Minangkabau perempuan membeli laki-laki, memberinya uang, maka laki-laki dan perempuan diperhubungkan oleh uang atau keturunan yang baik, sama sekali tidak dipertalikan cinta dan kasih saying. Hal ini menyebabkan mereka mudah bercerai sehingga budaya tersebut sangat berbeda dengan suami isteri bangsa Barat yang diperhubungkan dengan tali cinta dan kasih sayang yang hanya mengindahkan harta, bangsa, pangkat: lebih-lebih lagi mereka terikat oleh perjanjian tidak boleh bercerai sehingga hubungan suami isteri menjadi kokoh dan erat (hlm.206)

Dikemukakan Nurbaya, nasib malang perempuan yang ditindas laki-laki menganggap dirinya tuan dan perempuan adalah budaknya. Laki-laki menyangka dirinya lebih dari perempuan. Perempuan pihak lemah selalu mendapat pekerjaan yang serba susah: mengandung, melahirkan, mengasuh anak, bekerja di dapur, mencuci pakaian, dan membersihkan
Volume 3, Nomor 1, Januari 2021

ISSN 2655-3031 (P), 2655-7851 (O)

DOI: http://dx.doi.org/10.29300/disastra.v3i1.3481

rumah. Laki-laki tidak merasakan penanggungan, kesengsaraan, dan kesakitan perempuan, padahal ibunya sendiri adalah perempuan. Kadang isterinya sedang hamil ditinggalkan kawin lagi. Anak itu adalah anak mereka berdua, tetapi yang mengasuh perempuan; kalau anak itu kelak menjadi orang yang terkenal dan berbahagia, akan lebih dikenal sebagai anak ayahnya, bukan sebagai anak ibunya. Hal ini tidak adil (hlm.215)

Perempuan tidak mempunyai kebebasan, hanya mempunyai kebebasan sampai umur enam tahun, boleh berjalan kian ke mari, boleh bermain keluar rumah, tetapi sesudah itu harus masuk kurungan seperti burung, harus dipingit, dan sampai tua harus hidup di rumah dan di dapur saja. Itulah nasib perempuan bangsa Indonesia (hlm. 218).

Pada akhirnya, Siti Nurbaya mengemukakan tuntutan persamaan hak perempuan dengan laki-laki. meskipun tidak banya, sekedar yang perlu bagi kehidupan perempuan cukuplah. Hendaknya laki-laki memandang perempuan sebagai adiknya, biarlah perempuan menuntut ilmu yang berguna baginya (hlm. 222)

Setelah Siti Nurbaya termenung sejurus, berkatalah pula ia, seraya mengeluh, "memang demikianlah nasib kita perempuan. Adakah akan berubah peraturan kita ini? Adakah kita akan dihargai lakilaki, kelak? Biar tak banyak, sekedar cukuplah. Aku tiada hendak meminta, supaya perempuan disamakan benar-benar dengan laki-laki dalam segala hal; tidak, karena aku tidak mengerti juga, tentu tak boleh jadi. Tetapi permintaanku, hendaknya 
laki-laki itu memandang perempuan, sebagai adiknya, jika tak mau ia memuliakan dan menghormati Perempuannya, sebagai pada bangsa Eropa. Jangankan dipandangnya kita sebagai hamba atau makhluk hina. Biarlah perempuan menuntu ilmu yang berguna baginya, biarlah ia diizinkan melihat dan mendengar segala yang boleh menambah pengetahuannya; biarlah ia boleh mengeluarkan perasaan hatinya dan buah pikirannya, supaya dapat bertukar-tukar pikiran, untuk menajamkan otaknya. Dan berilah ia kuasa atas segala yang harus dikuasainya, agar jangan ia dengan boneka yang bernyawa saja" (hlm.222-223).

Dikemukakan Nurbaya, hendaknya rumah tangga dikelola bersama-sama antara suami dengan isteri, dengan pembagian kerja yang adil, jangan sampai suami isteri melanggar hak dan kewajiban masingmasing. Hak dan kewajiban isteri mengurus rumah tannga, menjaga anak, makanan, perkakas, dan lain-lainnya. Oleh sebab itu, perempuan harus paham dalam segala hal ini. Suami berhak dan berkewajiban mencari penghidupan, pekerjaan, mengurus perlindungan, dan lain-lain. Pendek kata, hidup suami isteri harus selaras, tidak ada yang lebih berkuasa, bekerja sama: "berat sama dipikul, ringan sama dijinjing" (hlm.223).

Selanjutnya dikemukakan Nurbaya, seharusnya suami isteri selalu mencari akal untuk menyenangkan temannya dan selalu menjaga jangan sampai sakit-menyakiti hati. Jika tumbuh silang selisih janganlah masing-masing hendak berada di hati dan bersutan di mata sendiri-sendiri saja karena
Volume 3, Nomor 1, Januari 2021 ISSN 2655-3031 (P), 2655-7851 (O) DOI: http://dx.doi.org/10.29300/disastra.v3i1.3481

hal ini akan membuat kusut kehidupan (hlm.224).

Inti sari dari paparan di atas bahwa, wanita bukan perhiasan sangkar madu. Menganggap wanita adalah budaknya, tidak diberi kebebasan. Pada akhirnya, Siti Nurbaya mengemukakan tuntutan persamaan hak perempuan dengan lakilaki. Hal tersebut terkait dengan emansipasi wanita seperti yang dikemukakan oleh Kartini, kebebasan melakukan sesuatu tanpa meninggalkan kewajibannya sebagai seorang istri.

\section{B. Novel Layar Terkembang Karya Sutan Takdir Alisyahbana}

Tuti sebagai wujud transformasi ide-ide kemajuan dan tokoh cita-cita emansipasi wanita seperti yang dikemukakan oleh Kartini. Hal ini digambarkan sebagai berikut: Tuti wanita yang insaf akan dirinya, insaf akan harga dirinya amat besar, tahu bahwa ia pandai dan cakap dan banyak yang dapat dikerjakan dan dicapainya. Segala sesuatu diukur dengan kecakapannya sendiri. Ia tidak turutmenurut dengan orang lain jika tidak sesuai dengan kata hatinya. Tuti seorang yang tegap dan kukuh pendiriannya, tak suka beri-memberi, bekerja keras dan berjuang untuk cita-cita yang menurutnya mulia dan luhur (hlm.7).

Ia seorang pemimpin perkumpulan wanita Puteri Sedar yang terkemuka yang meyakini bahwa keadaan perempuan bangsanya amat buruk nasibnya terikat oleh beratus-ratus ikatan, yang hanya harus menurut kehendak kaum laki-laki (hlm.15).

Uraian dalam Layar Terkembang, dalam pidato Tuti, mengemukakan 
kesengsaraan kaum perempuan sebangsa yang harus diperbaiki demikian.

"Saudara-saudaraku kaum perempuan, rapat yang terhormat! Berbicara tentang sikap perempuan baru sebahagian besar adalah berbicara tentang bagaimanakah harusnya kedudukan perempuan dalam masyarakat yang akan datang. Janganlah sekali-sekali disangka, bahwa berunding tentang cita-cita yang demikian semata-mata berarti berunding tentang angan-angan dan pelamunan yang tiada mempunyai guna yang praktis sedikit jua pun.

Saudara-saudara, dalam tiap-tiap usaha hanyalah mungkin kita mendapat hasil yang baik, apabila terang kepada kita, apa yang hendak kita kerjakan, apa yang hendak kita kejar dan kita capai. Atau dengan perkataan yang lain dalam segala hal hendaklah kita mempunyai gambaran yang senyata-nyatanya tentang apa yang kita cita-citakan. Demikianlah menetapkan bagaimana harus sikap perempuan baru dalam masyarakat yang akan datang berarti juga menetapkan pedoman yang harus diturut waktu mendidik kanak-kanak perempuan masa sekarang. Untuk sejelas-jelasnya melukiskan perempuan baru seperti yang dicitacitakan Putri Sedar, bagaimana sikapnya dan bagaimana kedudukannya dalam segala cabang masyarakat haruslah kita lebih dahulu menggambarkan seterangterangnya sikap dan kedudukan perempuan bangsa kita di masa yang silam" (Hlm. 32)

Untuk mengangkat derajat wanita dikemukakan Tuti bahwa pendidikan budi pekerti perempuan semata-mata ditujukan
Volume 3, Nomor 1, Januari 2021

ISSN 2655-3031 (P), 2655-7851 (O)

DOI: http://dx.doi.org/10.29300/disastra.v3i1.3481

untuk keperluan laki-laki. Segala sifat lemah itulah dijadikan sifat perempuan yang termulia: Perempuan mesti sabar, perempuan mesti lemah lembut, perempuan mesti pendiam. Berjalan perempuan tiada boleh lekas-lekas, berbicara dan tertawa tiada boleh keras-keras. Dalam segala hal ia harus halus.

Panjang lebar Tuti menerangkan pengaruh seorang ibu dalam didikan anak yang pertama yang dikemudian hari akan menjadi orang besar. Bahwa perempuanlah yang pertama kali memimpin anak dan menetapkan sifat-sifat yang mulia yang seumur hidup tidak berubah lagi dalam jiwa anak. Bahwa segala usaha untuk memperbaiki keadaan bangsa kita dapat berubah. Jadi perubahan kedudukan perempuan dalam masyarakat itu bukanlah semata-mata kepentingan perempuan. Kaum laki-laki yang insaf akan kepentingan yang lebih mulia dari kepentingan hatinya tentu akan harus mengakui hal itu (hlm.37).

Tuti tokoh yang konsekuen dengan pendirian emansipasi wanita, yaitu mempunyai pikiran sendiri sesuai dengan cita-cita kemajuan, cita-cita emansipasi. Kalau perlu wanita tak usah kawin jika tidak sesuai dengan emansipasi itu. Ia berpendirian sebagai berikut ini.

Dalam mengingatkan perhubungan dengan Hambali itu perlahan-lahan hatinya agak tenang. Sekaliannya nyata kelihatan tergambar kepadanya. Tidak, tidak, ia tidak pernah menyesal. Selalu ia berkata, apabila perkawinan menjadi ikatan baginya, bagi cita-cita dan pekerjaann hidupnya ia tidak kawin. Hanya satu pendirian itu saja yang

Tri Riya Anggraini 
1.PJDISASTRRA

sesuai dengan akal sehat (Alisyahbana, 1991:68).

Tetapi apabila seolah-olah telah putuslah maksudnya demikian oleh kemenangan perasaan hatinya, maka timbullah timbangan yang menyelidiki dan menyiasati keputusan yang diambilnya itu. "Baiklah ia kawin dengan Supomo? Dapatkah ia mencintai dan menghormatinya? Dapatkah ia memberi bahagia kepadanya sebagai suaminya? Dapatkah ia sendiri merasa berbahagia dengan Supomo, laki-laki yang lemah lembut, baik hati, tetapi biasa dalam segala-galanya dan tiada sedikit turut hidup dengan pergerakan kebangunan bangsanya?" (hlm.103).

Akhirnya setelah Tuti mendapatkan laki-laki yang sesuai dengan pendiriannya, sesuai dengan emansipasinya, ia mau menerimanya Yusuf, tunangan adiknya. Hal ini didukung karena kondisi maria yang telah kronis.

"Alangkah berbahagia saya rasanya di akhirat nanti, kalau saya tahu, bahwa kakandaku berdua hidup rukun dan berkasih-kasihan seperti kelihatan kepada saya dalam beberapa hari ini..."

"Inilah permintaan saya yang penghabisan dan saya, saya tidaklah rela selama-lamanya, kalau kakandaku masing-masing mencari peruntungan pada orang lain." (hlm.135).

Dari paparan di atas, maka dapat dinyatakan bahwa Tuti yang digambarkan sebagai wanita pandai dan cakap dan banyak yang dapat dikerjakan dan dicapainya . segala sesuatu diukur dengan kecakapannya sendiri. Ia tidak turut
Volume 3, Nomor 1, Januari 2021

ISSN 2655-3031 (P), 2655-7851 (O)

DOI: http://dx.doi.org/10.29300/disastra.v3i1.3481

menurut dengan orang lain jika tidak sesuai dengan kata hatinya. Tuti seorang yang tegap dan kukuh pendiriannya, tak suka beri-memberi, bekerja keras dan berjuang untuk cita-cita yang menurut pikirannya namun tetap pada memilih laki-laki sesuai dengan pemikirannya dan emansipasinya.

Teknik ekserp dan modifikasi yang paling banyak diterapkan dalam proses transformasi terhadap hipogram dalam penelitian ini ternyata mengandung maksud untuk memberi pengetahuan kepada pembaca terhadap kodrat seorang wanita yang sesungguhnya. Penggambaran secara jelas mengenai peran wanita, hak dan kewajibannya sebagai seorang istri dalam kehidupan rumah tangga juga dilukiskan oleh pengarang melalui kalimat-kalimat yang diucapkan Nurbaya dalam percakapannya dengan Alimah dan Ahmad Maulana. Serta Tuti pada pidatonya dalam Kongres Putri Sedar. Bahwa seorang wanita tidak harus tunduk terhadap segala peraturan adat yang berlaku yang membuat wanita menjadi manusia bodoh dan tidak berguna. Pengarang juga secara jelas menggambarkan sosok perempuan modern yang menghargai waktu, mau belajar, tidak gila harta dan gila sanjungan, serta wanita yang taat menjalankan ibadahnya sebagai makhluk yang beragama.

Teknik ekserp sangat membantu pengarang untuk menggambarkan perjuangan dan cita-cita dari sosok Kartini seorang pejuang yang menegakkan emansipasi wanita sehingga kedudukan wanita dapat sama dengan laki-laki. Pengarang juga menunjukan sikap protesnya terhadap adat yang masih melekat pada bangsa Indonesia. Para wanita tidak 
dapat mengeyam pendidikan tinggi padahal di tangan merekalah selanjutnya generasi penerus akan berkembang dan memajukan zaman. Bahkan keinginan Kartini untuk tidak menikah juga digambarkan pengarang dengan watak Tuti yang keras dan ideal. Hingga akhirnya Kartini memutuskan untuk menikah dengan laki-laki yang dicintainya dan mampu menghargai setiap usahanya demi mewujudkan cita-cita yang mulia juga diserap oleh pengarang dalam novelnya. Hal ini membuat pengarang menjadi bebas untuk melukiskan keinginannya dalam usaha meningkatkan kedudukan seorang wanita dalam masyarakat.

Teknik modifikasi yang digunakan pengarang dimaksudkan untuk memperluas isi cerita. Tokoh Nurbaya dimodifikasi menjadi seorang yang hanya pasrah menerima nasib sebagai perempuan yang lemah. Nurbaya hanya berjuang sebatas kemampuannya. Berbeda dengan karakter Kartini yang keras dan tegas sangat memperjuangkan persamaan hak antara laki-laki dan perempuan.

Dari uraian di atas tampak bahwa resepsi Marah Rusli terhadap tokoh Kartini dalam novel "Siti Nurbaya" ini merupakan simbol feminisme, yang mengutamakan kesamaan hak antara laki-laki dan perempuan. Melalui perjuangan Kartini sebuah paradigma yang lama terhadap dapat diubah. Bahwasanya seorang perempuan hanyalah sebagai hamba sahaya kaum lakilaki kini mendapat citra baru, yaitu wanita Indonesia yang berpendidikan dan berpikir maju.

Seperti halnya resepsi Marah Rusli terhadap Kartini, Takdir juga mentransformasikan tokoh Kartini dalam novelnya yang mengangkat seputar dunia
Volume 3, Nomor 1, Januari 2021 ISSN 2655-3031 (P), 2655-7851 (O) DOI: http://dx.doi.org/10.29300/disastra.v3i1.3481

perempuan modern. Melalui mulut Tuti dikemukakan pikiran-pikiran Takdir tentang peranan dan kedudukan wanita yang mempunyai hak-hak yang sama dengan kaum pria.

Baik novel Siti Nurbaya maupun Layar Terkembang ditransformasikan pengarangnya secara utuh mengenai konsep gagasan emansipasi wanita melalui tokoh Kartini. Meskipun demikian keduanya tentu terdapat perbedaan dalam ceritanya. Novel Layar Terkembang dapat memberi jawaban terhadap persoalan yang ditinggalkan dalam novel Siti Nurbaya. Intisari dari kisah yang diceritakan dalam novel ini berupa percintaan tokoh-tokoh muda terpelajar dengan akhir menggembirakan berupa perkawinan dari kedua tokohnya. Hal inilah yang membedakannya dengan Siti Nurbaya yang tokohnya gagal membangun cita-cita dan harapan.

\section{Simpulan}

Prinsip horizon harapan terhadap penerimaan gagasan emansipasi wanita melalui tokoh Kartini diterapkan oleh Marah Rusli dalam novel Siti Nurbaya maupun dalam novel Layar Terkembang oleh Sutan takdir Alisyahbana. Hal ini dapat dilihat melalui pengembangan hipogram dengan menggunakan teori Pradotokusumo yaitu, Modifikasi dan ekserp.

Konsep R.A. Kartini yang dimanipulasi oleh Marah Rusli dan Takdir ini menunjukan pemahaman terhadap gagasan emansipasi wanita yang sesungguhnya. Siti Nurbaya yang dikemas oleh Marah Rusli dengan mengadaptasi budaya lokal Minangkabau. Sedangkan, Layar Terkembang dikemas oleh Takkdir dengan budaya lokal masyarakat Jawa. 
Perbedaan keduanya ditunjukan pada akhir cerita. Tuti dalam Layar Terkembang mewujudkan keinginan Kartini, menikah dengan lelaki pilihannya, Yusuf. seorang pria yang berpendidikan lulusan kedokteran, menghargai perjuangan tuti mengangkat kedudukan wanita agar wanita memiliki pengetahuan luas dan cerdas, tetapi tetap dalam kodratnya saat ia menjadi seorang anak, istri, dan sebagai ibu.

Hal inilah yang kemudian dilakukan pengarang dalam mereaksi Surat-surat Kartini tampak adanya gagasan emansipasi wanita yang mengebu-gebu diperjuangkan oleh pengarang lewat tokoh-tokohnya sehingga tercipta sebuah apresiasi sastra baru oleh sastrawan Indonesia.

\section{Daftar Pustaka}

Alisyahbana,Sutan Takdir. (1991). Layar Terkembang. Jakarta: Balai Pustaka.

Endraswara, Suwardi. (2008). Metodologi Penelitian Sastra. Yogyakarta: MedPress.

Fairclough, Norman. (1995). Discourse and Social Change. Great Britain: TJ Press.

Islami, Widyani Nurul. (2008). "Relevansi Pemikiran Pendidikan R.A. Kartini dengan konsep Feminisme dalam Pendidikan Islam”. Skripsi. STAIN Ponogoro. Skripsi tidak diterbitkan

Ma'ani, Achmad Syafi'I. (2013). Agama Politik Moral. Malang: Anggota IKPI.

Munandar, U. (Ed). (1985). Proseding Seminar Emansipasi Wanita Harapan atau Kenyataan dan Seminar Peran Ganda Wanita Dalam Pembangunan Bangsa. Jakarta: Universitas Indonesia Press.
Volume 3, Nomor 1, Januari 2021 ISSN 2655-3031 (P), 2655-7851 (O) DOI: http://dx.doi.org/10.29300/disastra.v3i1.3481

Pradopo, Rachmat Djoko. (1995). Beberapa Teori Sastra, Metode Kritik, dan Penerapannya. Yogyakarta: Pustaka Pelajar.

Ratnawati, Latifah. (2001). "Menelusuri Perjalanan Konsep Tokoh Sita". Lingua Jurnal Bahasa Dan Sastra. 3 (1): $17-25$.

Rusli, Marah. (1968). Siti Nurbaya. Jakarta:Balai Pustaka.

Subandiah, Heny. (1996). Citra Perempuan dalam Novel Namaku Hiroko Makalah dalam mimbar Ilmiah. Surabaya: FBS, Unesa.

Sutrisno, Sulastin. (1985). Surat-Surat Kartini Renungan tentang dan untuk Bangsanya. Jakarta: Djambatan.

Tong, Rosemary Putnam. (2006). Feminist Thought (Pengantar Paling Komprehensif Kepada Arus Utama Pemikiran Feminis). Yogyakarta: Jalasutra.

Wahono, H \& Sumartini. (2015). "Pengaruh Kekuasaan Laki-laki terhadap Perempuan dalam Novel The Chronicle Of Kartini Karya Wiwid Prasetyo: Kajian Feminisme". Jurnal Sastra Indonesia, 4(1), 1-9. 